\title{
A STUDY ON FINGERPRINT PATTERN OF RIGHT HAND OF MEDICAL STUDENTS
}

\author{
N. A. Balaram ${ }^{1}$, Parthasarathy K. $S^{2}$ \\ 1 Professor and HOD, Department of Forensic Medicine, Government Medical College, Thrissur, Kerala. \\ ${ }^{2}$ Assistant Surgeon, District Hospital, Wadakkancherry, Thrissur, Kerala.
}

ABSTRACT
BACKGROUND
Determination of individuality or identification is one of the prime issues in forensic practice. Identification is the determination of
the characteristics by which one individual is distinguished from the others. Among the various parameters used for identification,
one that stands out and is extensively used is fingerprints.

\section{MATERIALS AND METHODS}

This study was conducted on 250 (125 males and 125 females) MBBS students from Government Medical College, Thrissur, Kerala, within a time period of one and a half years. The materials used for this study are a digital fingerprint scanner. The fingerprint patterns were identified and analysed.

\section{RESULTS}

Loops were the predominant pattern followed by whorls, composites and arches. Each pattern showed a preponderance to a particular finger.

\section{CONCLUSION}

Loops were the predominant pattern in right hand, followed by whorls, composites and arches. Loops were most predominant in middle and little fingers and found in the least number in index finger. Whorls were most predominant in the ring finger and found in least number in little finger. Composites were seen in maximum number in the thumb and was rare in little finger. Arches were in the highest frequency the index finger and was found in least in the thumb.

\section{KEYWORDS}

Identification, Fingerprints, Right Hand.

HOW TO CITE THIS ARTICLE: Balaram NA, Parthasarathy KS. A study on fingerprint pattern of right hand of medical students. J. Evolution Med. Dent. Sci. 2017;6(57):4257-4260, DOI: 10.14260/Jemds/2017/922

\section{BACKGROUND}

Determination of individuality or identification is one of the prime issues in forensic practice. Identification is the determination of the characteristics by which one individual is distinguished from the others. This is important in the identification of criminals and other persons, dead bodies or human remains. Identity is a part and parcel of corpus delicti or the body of crime. ${ }^{1}$

Some of the important parameters usually noted for the purpose of identification are race, gender, age, skin texture and features, speech and voice, footprints, fingerprints, deformities, hair, tattoo marks, scars, occupational marks, handwriting, garments and personal articles, gait pattern and DNA profile. This may lead to either circumstantial identification or positive identification. Out of all these parameters, one that stands out and is extensively used is fingerprints. ${ }^{2}$

Dermatoglyphics (Ancient Greek, derma=skin, glyphe=furrow) is the term applied to the scientific study of prints of skin viz., fingerprints, footprints and palm prints. ${ }^{3}$

Financial or Other, Competing Interest: None.

Submission 26-06-2017, Peer Review 09-07-2017,

Acceptance 11-07-2017, Published 17-07-2017.

Corresponding Author:

Dr. Parthasarathy. K. S

Assistant Surgeon, District Hospital,

Wadakkancherry, Thrissur, Kerala.

E-mail: parthasarathy.ks@gmail.com

DOI: $10.14260 /$ jemds $/ 2017 / 922$

Fingerprints are characterised by alternating strips of raised friction ridges and depressed grooves on the palmar surface of the fingertips. Fingerprints are formed within the womb at approximately 12 weeks of gestation. ${ }^{4}$ They are fully formed by the 25 th week and are permanent for life. ${ }^{5}$ The identification using fingerprints is done by comparing many details of characteristics called as minutiae, which occur throughout the ridge areas, example ridge termination, bifurcation, etc.

In India, there is "hastha rekha sasthram" from $20^{\text {th }}$ century B.C., which describes prints and lines in the hand to connect it with the individuality and fate of a person. ${ }^{6}$

Galton published a detailed statistical model of fingerprint analysis and identification and encouraged its use in forensic science in his book fingerprints. He had calculated that the chance of a "false positive" (two different individuals having the same fingerprints) was about 1 in 64 billion. $^{7}$

\section{History of Fingerprint in India}

In India, there are references to the nobility using friction ridge skin as signatures. In A.D. 1637, the joint forces of Shah Jahan and Adil Khan under the command of Khan Zaman Bahadur invaded the camp of Shahuji Bhonsle, the ruler of Pona (in the present-day Maharashtra). The joint army defeated Shahuji who was compelled to accept the terms of peace. Since the garrison (of Shahuji) was now reduced to great extremities, Shahuji wrote frequently to Khan Bahadur in the humblest strain promising to pay allegiance to the 
crown. He at the same time solicited a written treaty stamped with the impression of his hand.

The above text is an example of the nobility's use of palm prints in India to demonstrate authenticity of authorship when writing an important document. It is believed that the use of prints on important documents was adopted from the Chinese, where it was used generally, but in India, it was mainly reserved for royalty. ${ }^{8}$

In 1858, Herschel experimented with the idea of using a handprint as a signature by having a man named, Rajyadhar Konai, to put a stamp of his right hand on the back of a contract for road-binding materials. The contract was received and accepted as valid. This spontaneous printing of Konai's hand, thus led to the first official use of friction ridge skin by a European. The success of this experiment led Herschel to begin a long exploration of friction ridge skin, and over the next year, he went on to collect multiple fingerprints from family, friends, colleagues, and even himself. In 1860, he was promoted to magistrate and given charge of Nuddea, a rural subdivision in Bengal. While there, he recognised more identification possibilities for the use of friction ridge skin, especially in fighting and preventing fraud. In 1877, Herschel was able to institute the recording of friction ridge skin as a method of individualisation on a widespread basis. Herschel was in charge of the criminal courts, the prisons, the registration of deeds and the payment of government pensions, all of which he controlled with fingerprint identification.

In 1894, Sir Edward Richard Henry, Inspector General of Police for the Lower Provinces, Bengal, collaborated with Galton on a method of classification for fingerprints. With the help of Indian police officers, Khan Bahadur Azizul Haque and Rai Bahaden Hem Chandra Bose, the Henry Classification System was developed. Once the classification system was developed and proved to be effective, Henry wrote to the Government of India asking for a comparative review of anthropometry and fingerprints. Charles Strahan, Surveyor General of India and Alexander Pedler, a chemist, were sent to Bengal to meet with Henry to investigate the two methods of identification. Toward the end of March 1897, they sent a report to the Government of India that stated, "In conclusion, we are of opinion that the method of identification by means of fingerprints as worked on the system of recording impressions and of classification used in Bengal, maybe safely adopted as being superior to the anthropometrics method"-

1. In simplicity of working,

2. In the cost of apparatus,

3. In the fact that all skilled work is transferred to a central or classification office,

4. In the rapidity with which the process can be worked,

5. In the certainty of the results, thus in 1897, the Government of India sanctioned the sole use of fingerprints as a means of identification for prisoners. The world's first fingerprint bureau was setup in Bengal in 1897.

As of March 2013, the Unique Identification Authority of India (UIDAI) operates the world's largest fingerprint (multimodal biometric) system, with over 200 million fingerprint, face and iris biometric records. UIDAI plans to collect as many as 600 million multimodal records by the end of 2014. India's unique identification project is also known as Aadhaar, a word meaning "the foundation" in several Indian languages. Aadhaar is a voluntary program with the ambitious goal of eventually providing reliable national ID documents for most of India's 1.2 billion residents.

With a database many times larger than any other in the world, Aadhaar's ability to leverage automated fingerprint and iris modalities (and potentially automated face recognition) enables rapid and reliable automated searching and identification impossible to accomplish with fingerprint technology alone, especially when searching children and elderly residents fingerprints.

\section{MATERIALS AND METHODS}

This descriptive study was conducted on 250 (125 males and 125 females) MBBS students (by simple stratified method) from Government Medical College, Thrissur, Kerala, within a time period of one and a half years. The materials used for this study are a digital fingerprint scanner (USB Futronic's FS80) and a computer for storing the scanned fingerprints.

The students are properly explained about the objectives of the intended study and consent was taken. They were asked to wash and dry their hands to remove dirt, sweat and grease. The prints were taken with the fingers applied on the fingerprint scanner and were stored in the computer. In this way for each and every individual, the entire prints of five fingers of right hand were prepared. The fingerprints were classified broadly into their four types namely, loops, whorls, arches and composites to find out the frequency of distribution of the fingerprint patterns in the students.

\section{RESULTS}

In the right hand of all subjects, it was seen that loops $(57.76 \%)$ were the most common pattern followed by whorls (30.16\%), composites (7.2\%) and arches (4.88\%). Arches were seen in maximum numbers in index finger, composites in thumb, loops in little finger and whorls in ring finger as shown in Figure 1.

Arches were seen in the least number with the maximum number of arches in index finger (54\%) and was equally distributed among ring and little finger $(9.83 \%)$ and found in least numbers in the thumb (4.9\%) as seen in Table 1.

Composites were seen in next higher frequency with majority of them in the thumb (57\%) followed by index finger $(23 \%)$ and were at least seen in little finger $(2.2 \%)$ as seen in Table 1.

Whorls were the second highest in frequency with one third of the whorls in the ring finger followed by index finger (24\%) and thumb (19\%) and were found in the least numbers in middle and ring finger $(11 \%)$ as seen in Table 1.

Loops were the most predominant type with maximum number in little finger (28\%) closely followed by middle finger $(25 \%)$ and the least number was recorded in index finger (14\%) as seen in Table 1. 


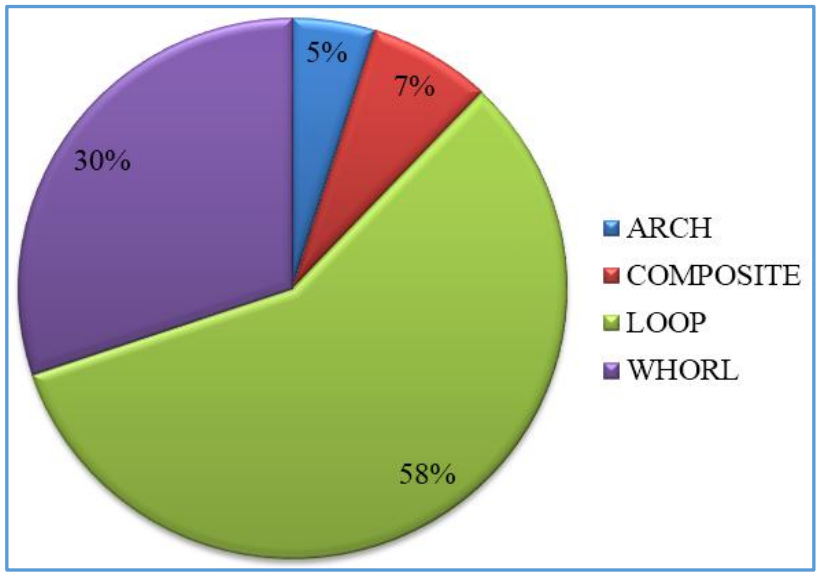

Figure 1. Distribution of Fingerprint Pattern in Right Hand of all the Subjects

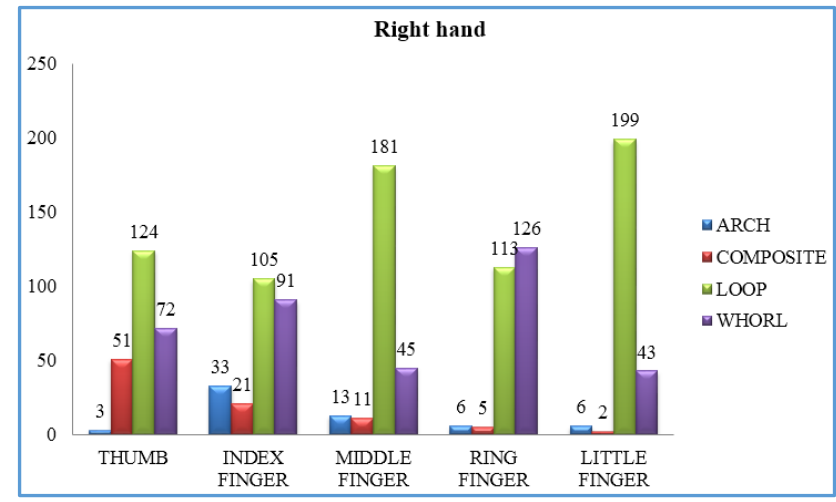

Figure 2. Distribution of Fingerprint Pattern in Right Hand in Individual Fingers

\begin{tabular}{|c|c|c|c|c|c|c|}
\hline Right Hand & Thumb & Index Finger & Middle Finger & Ring Finger & Little Finger & Total \\
\hline Arch & $3(4.9 \%)$ & $33(54.09 \%)$ & $13(21.31 \%)$ & $6(9.83 \%)$ & $6(9.83 \%)$ & $\mathbf{6 1}(\mathbf{4 . 8 8} \%)$ \\
\hline Composite & $51(56.66 \%)$ & $21(23.33 \%)$ & $11(12.22 \%)$ & $5(5.55 \%)$ & $2(2.22 \%)$ & $\mathbf{9 0}(\mathbf{7 . 2 \% )}$ \\
\hline Loop & $124(17.17 \%)$ & $105(14.54 \%)$ & $181(25.07 \%)$ & $113(15.65 \%)$ & $199(27.56 \%)$ & $\mathbf{7 2 2}(57.76 \%)$ \\
\hline Whorl & $72(19.09 \%)$ & $91(24.14 \%)$ & $45(11.93 \%)$ & $126(33.42 \%)$ & $43(11.40 \%)$ & $\mathbf{3 7 7}(\mathbf{3 0 . 1 6} \%)$ \\
\hline \multicolumn{7}{|c|}{ Table 1. Distribution of Fingerprint Pattern in Right Hand in Individual Fingers } \\
\hline
\end{tabular}

\section{DISCUSSION}

Among the fingerprint patterns studied, majority of them were loop pattern followed by whorl, arch and composite pattern. This was similar to the results obtained by Binorkar Sandeep V, Kulkarni Anand B, ${ }^{9}$ Mehta Amit A and Mehta Anjulika A. ${ }^{10}$

The study conducted by Khadri Sayed Yunus, Goudar ES and Khadri Sayeda Yasmeen ${ }^{11}$ showed that the predominant pattern among both male and female was ulnar loop pattern $(38.42 \%)$ in male and $(44.56 \%)$ in female followed by plain whorl pattern $(24.04 \%)$ in male and $(18.24 \%)$ in female, respectively.

Although, the study conducted by Kanchan Tanuj, Chattopadhyay Saurabh ${ }^{12}$ on Indian medical students stated that the frequency of distribution of fingerprint patterns was variable and the frequency of whorl pattern was comparatively higher than that of loop pattern contrary to our results. The predominance of loop pattern was higher in the ring finger and little finger that of whorl pattern was higher in the ring finger. There was a definite preponderance of arches on the index finger. Similar results were obtained by Kanchan et al.

The study on south Indian fingerprint pattern by Nithin Mathew Sam, Rema P, Venugopalan Nair B ${ }^{13}$ showed similar findings with $57.1 \%$ loops, $30.4 \%$ whorls, $6.4 \%$ composites and $6.2 \%$ arches.

Dr. Prateek Rastogi and Ms. Keerthi R Pillai ${ }^{14}$ conducted a prospective study in 2010, among 200 medical students (100 male and 100 female) belonging to the age group 18-25 of Kasturba Medical College, Mangalore, India. Results show that each fingerprint is unique and loops are the most commonly occurring fingerprint pattern while arches are the least common, which was similar to the results obtained by us.

Londhe SR, Jadhav AS15 conducted a study in V.M. Government Medical College, Solapur, India. Results show that the frequency of loops was significantly highest in all subjects followed by whorls and arches. There was a high frequency of loops in middle and little fingers. Whorls were found in highest frequency in ring fingers and arches were in highest frequency in Index fingers. The results obtained were much similar to the observations made in our study.

The pattern distribution of individual fingers showed a maximum number of loops in little finger, whorls in ring finger and arches in index finger, which was similar to studies conducted by Amit A. Mehta and Anjulika A. Mehta. ${ }^{10}$

\section{CONCLUSION}

- Loops were the predominant pattern in right hand, followed by whorls, composites and arches.

- Loops were most predominant in middle and little fingers and found in the least number in index finger.

- Whorls were most predominant in the ring finger and found in least number in little finger.

- Composites were seen in maximum number in the thumb and were rare in little finger.

- Arches were in highest frequency in the index finger and were found in least in the thumb.

\section{REFERENCES}

[1] Guharaj V, Chandran MR. Personal identity. Forensic medicine. $2^{\text {nd }}$ edn. Universities Press 2009:P 8.

[2] Bansal HD, Badiye AD, Kapoor NS. Distribution of fingerprint patterns in an Indian population. Malaysian Journal of Forensic Sciences 2014;5(2):18-21.

[3] Cummins H, Midlo C. Palmar and plantar epidermal ridge configurations (dermatoglyphics) in European Americans. American Journal of Physical Anthropology 1926;9(4):471-502.

[4] Payne-James J, Jones R, Karch SB, et al. Simpson's forensic medicine. 13th edn. London: Hodder \& Stoughton Ltd 2011:P 227.

[5] Penrose LS, Ohara PT. The development of the epidermal ridges. J Med Genet 1973;10:201-8.

[6] Ignatius PC. Identity. Forensic medicine and toxicology. 1st edn. My lecture notes 2014:P 101. 
[7] Francis G. Fingerprints. London: MacMillan and Co 1892:P 110.

[8] Sodhi GS, Kaur J. Indian civilisation and the science of fingerprinting. Indian $\mathrm{J}$ of Traditional Knowledge 2003;2(2):126-36.

[9] Sandeep VB, Kulkarni AB. Study on the fingerprint pattern and gender distribution in and around Nande district of Maharashtra state. Eur J Forensic Sci 2017;4(1):7-11.

[10] Mehta AA, Mehta AA. Study of fingerprint patterns among medical students in Vidarbha region, India. Int J Anat Res 2015;3(2):1043-5.

[11] Yunus KS, Goudar ES, Khadri SY. A study of fingerprint pattern and gender distribution of fingerprint in and around Bijapur. Al Ameen J Med Sci 2013;6(4):328-31.
[12] Kanchan T, Chattopadhyay S. Distribution of fingerprint patterns among medical students. JIAFM 2006;28(2):65-8.

[13] Sam NM, Rema P, Venugopalan NB. Study of fingerprint patterns in South Indian population. J Indian Acad Forensic Med 2015;37(4):369-73.

[14] Rastogi P, Pillai KR. A study of fingerprints in relation to gender and blood group. J Indian Acad Forensic Med 2010;32(1):11-4.

[15] Londhe SR, Jadhav AS. Digital dermatoglyphic and ABO blood groups. Indian J Forensic Medicine and Pathology 2011;4(2):77-81. 